\title{
Transformational Giving and its Relationship to the Emerging Roles of Public Colleges and Universities
}

Received (in revised form): June 18, 2007

\section{John C. Burkhardt}

is Director of the National Forum on Higher Education for the Public Good and Professor of Clinical Practice at the Center for the Study of Higher and Postsecondary Education, University of Michigan.

\begin{abstract}
Senior leaders whose job it is to advance the work of public colleges and universities frequently position and leverage the work of their institutions as serving the public good. In doing so, there are frequent references made to the potential role of philanthropy in transforming society by focusing institutional attention on its most daunting challenges. This paper reflects on how transformational giving relates to the expansion of the public university mission and examines how engagement with society in addressing its problems creates new opportunities as well as challenges for giving relationships. It falls to university presidents and senior advancement leaders to pay close attention to the ways that significant gifts set universities on a course of change.
\end{abstract}

\footnotetext{
Author's Contact Address:

John C. Burkhardt

Professor, Center for the Study of Higher and

Postsecondary Education

Director, National Forum on Higher Education

for the Public Good School of Education Building

610 East University Street, Suite 2339

Ann Arbor, Michigan 48109-1259, USA

Phone: +1 7346158882

E-mail: jcbforum@umich.edu
}

The paper challenges traditional approaches to higher education's role in responding to complex societal issues, and helps to clarify two oftenused but misunderstood concepts in the advancement professiontransformation and transaction. International Journal of Educational Advancement (2007) 7, 155-164. doi:10.1057/palgrave.ijea.2150057

Keywords:

transformational giving, public good, engagement

\section{Introduction}

We are approaching the 400th year of higher education's role in defining and promoting the American experience even though as a nation we are not yet 250 years old. The contributions of public higher education, when compared with those made by private colleges, are different and reflect a more-contemporary historical setting. In fact, the influence of our great public system of colleges and universities is something that is newly revealed-and often redefined it seems-in each quarter century (Veysey, 1965; Cohen, 1998). Even 
since the end of World War II, we have seen significant changes in the ways higher education relates to the continuing evolution of a pluralistic capitalistic democratic republic on this continent and how the expanding work of colleges and universities contributes to our nation's place in world leadership (Association of American Colleges and Universities, 2002; Nemec, 2006).

Public attitudes and especially the public's expectations of colleges and universities are an important factor in influencing the future of higher education as a social institution (Duderstadt and Womack, 2003; Chambers, 2005). While general public opinion of colleges and universities remains high (Serlingo, 2003; Immerwahr, 2004), the ways in which the work of higher education is understood by the public may not align with the ways in which college and university faculty and officials may view what they do (Institute for Higher Education Policy, 1998; National Forum on Higher Education for the Public Good, 2002). Therefore a discussion of how higher education "advances" itself and how it seeks means of its ongoing "development," if these words are taken literally, must begin with an understanding that the society we serve is changing (again-or perhaps still) in its needs and expectations. Accordingly, we in the academy are changing in relation to it. In the opening article of this special issue, David Weerts elaborates upon this general assertion as he connects the future of work of advancement with the emerging roles, purposes, and mission of higher education in a changing national context. While he faithfully references the many writers who have already asserted this claim, perhaps Weerts' most important contribution (in addition to that of editing this volume) is to draw our attention to the implications for work in the general area of higher education philanthropy, and to examine several strategies for summoning aid for what historian John Thelin describes as "the troubled giant" (Thelin, 2004, p. 147).

The articles that follow in this issue all provide valuable additional insights into this complex task of relating, enlarging, and leveraging the higher education enterprise within a society that is uniquely heavy with resources and yet laden with challenges. In article two, Shelley Strickland's welldocumented historical and analytical piece draws on previous research and the few available studies in building a theoretical framework for interpolating "engaged philanthropy" in service to more "engaged" colleges and universities.

The other authors who follow in this issue take up the theme in a pragmatic fashion, examining the implications of the general case in the immediate contexts of several public universities. Consideration is given to mission, history, and the roles typically associated with these institutions. Among urban institutions, Mark Langseth and Cassie McVeety take a close look at Portland State University, an institution that effectively repositioned itself within its region and within US higher education over a tenyear period. Jay Blanton's article on public engagement, communications, and public relations is particularly useful and practical in light of its implications for university development officers. The work by Victor Bloomfield and Michelle Kuhl 
considers a specific academic initiative that takes place within the University of Minnesota but reaches out across many research university settings. They apply what might be seen as the ultimate test of mission by gauging the effect of university engagement, development practices, and how this shapes the creation of knowledge, teaching, and learning in certain socially important disciplines. Their work can be placed within a larger national discussion about the changing roles of land grant universities in the United States.

In this paper, I wish to focus on some of the perplexing dilemmas that await a public university president, senior development executive, or others who must think seriously about how changes in the way that public higher education serves society will be reflected in the organization and practice of philanthropy. I am hopeful that these considerations will be helpful beyond those numbered audiences, but I already know that I do not have a recipe for advising a major gift officer on how to generate bigger gifts or instructions that will help an alumni director attract more graduates to homecoming weekend. In fact, this paper could place a clog in the inexorable pipeline of new tactical approaches to increase fund raising and it could be a distraction for some whose immediate job is to "simply" bring more support to a deserving enterprise.

But recognizing that the professional discourse needed to dramatically reorient and advance the field must also include an examination of its underlying principles gives me the responsibility (if not the authority) to pose a series of observations and challenges, which I believe need further, closer consideration. In approaching this, I reflect upon the fact that the field of advancement and the study of philanthropy draw on many different academic disciplines, both some that we would describe as basic and some that we would call applied (Payton, 1988). In this paper I am going to proceed through the construction and exploration of relatively simple posited assertions, a form of discourse familiar to philosophy, mathematics, ethics, and my own field of leadership study. While there is a risk that writing in this vein may seem pedantic, it is very intentional in its design. The best outcome may be that readers will clarify their own beliefs and generate their own thoughts about the claims that I offer, and that the formal and informal discussion about advancement, development, and the future of higher education might somehow be affected by a process in which different questions are raised and addressed in our professional conversations.

Public institutions of higher education have been positioned as places for solving society's most complex problems, just as there is a major shift occurring in the way that we understand, approach and address such challenges.

In no small part due to our own rhetoric and that of our own educational leaders, public colleges and universities have been positioned as places capable of great cures for the maladies of our age (Bush, 1945; Geiger, 1993; Kerr, 2001). In addition to turning out generations of capable 
graduates, higher education now provides the context for much of the nation's intellectual capacity in medical research, engineering, the life sciences, social science, and the humanities. Partnerships between government, industry, and the academy to organize the nation's intellectual work have exploded in the last 50 years, aided in many ways by the influence of the development and advancement functions within the university and the infusion of government investments (Cohen, 1998). This consolidation of capacity in public (and a few highprofile private) institutions has become a defining nature of the modern major research university.

But just like Calculus II, the problems keep getting harder to solve. In fact, we are coming to realize that some of the problems we are tackling were the solutions to problems just a generation or two ago (Walshok, 1995; Strauss and Howe, 1997). The problem of climate change requires, or so it now seems clear, a serious consideration of the ways in which technical progress and economic development are affecting the planet. Research in the field of nuclear energy is as concerned with expansion along side the problems of proliferation. Advancements in medicine have given life to new questions for ethicists and legal scholars. Politically and socially, some of our most perplexing issues center on fixing old solutions: social security, healthcare, public education.

When colleges and universities ascend the stage as problem solvers in this new era of complexity, they must be prepared to deal with the potentially serious effects on their own institutional consciousness in some way. Transformational challenges do not only change the set of possible outcomes that are available in response to a given problem, they also transform the environment for the problem and they change the problem solvers as well. Evidence for this is abundant, whether we cite the journals written by scientists working on the Manhattan project in the 1940s (see the chapter on the post-war writings of Robert Oppenheimer, in Gardner and Laskin, 1995), the dramatic physical changes on our campuses that reflect investment in military funding during the Cold War (Cohen, 1998), or the race to build life-science laboratories in the 1990s. The university (its people, its facilities, its culture, and its future opportunities) has been transformed by the problems it has chosen to solve.

It is important that higher education continues to serve society by addressing serious problems of many sorts. But a reflective university president and senior development officer must be mindful of the effect that this positioning of higher education in society is having on the collective preoccupations of the enterprise at large. It might be said that academic communities become what they think about. It should not surprise us that major research universities are increasingly corporate in their organization and problem-focused in their distribution of talent and resources. It might be compared to feeding one part of a plant or focusing a child's mind on one type of task. Over time, capacities become distorted and what is not used is lost.

Our societal understanding of "public" and "private" is becoming increasingly blurred. This applies to how institutions are situated within the 
political and social economy and also to how various problems are categorized for attention.

Perhaps there was a time when the distinction between public and private activity within our social economy was clearly determined by the type and source of transactions that shaped the enterprise under consideration. Principal among these transactions was the source of funding, and closely following was the origin of authority vested in the governance of the institution. By these definitions, the private or public nature of many of our major research universities has been changed, frequently split (Lyall and Sell, 2006). Over 25 years or more, the ratio of state (public) funding for the enterprise as a whole has diminished relative to other sources (Becker and Lewis, 1992; Duderstadt and Womack, 2003). While governance structures have remained in public control, these are often changing too, as the effect of "private" interests shape political processes and the appointment of regents and trustees becomes more partisan and resides, in effect, in the control of political parties.

The expansion of fund-raising and development efforts in public universities has gone hand-in-hand with the trend of "privatization" of our public institutions. While this phenomenon is defended as a response to the need to substitute private funding for public funding in many cases (Strout, 2007a), it has also had the effect of changing de facto control over some university decisions and priorities (Boyer, 1990; Baldwin and Krosteng, 1995; Gumport, 2000; Ehrenberg, 2006). The impact on the subsidiary activities closely aligned with the development function (athletics, brand marketing, access to donor events) is quite clear. Where there may have been a time that virtually anything that occurred on a university campus was a "public" event, now it is not uncommon for development events to become "private" affairs. This is more than a matter of language.

Our best university presidents would not countenance a shift in the essential mission of a great public university to be premised on a transactional promise such as the size of a single private gift. But over time, the broader patterns of support and the ways in which these insidiously come to shape all sorts of decision making at all levels within the university (many taken in no easy reach of the most attentive chief executive) do place a toll on the public nature of the university. Some might argue that distributing access more broadly to alumni and donors actually contributes to the realization of public control. The greater question resides in the effect on the university's inherent public purposes: are these furthered or constrained by the influence of private support?

The appeal of "institution building" has waned. It may be replaced by a desire to transform institutions and sets of problems simultaneously and philanthropy within higher education plays a special role in this.

Shelley Strickland's article in this special issue provides a historical reminder of the motivations held by high-profile donors to colleges and universities to engage in some form of institution building through 
philanthropy. These gifts came during a period when the institutional infrastructure of colleges and universities was still being put in place, and many of them were directed to the establishment or repositioning of a few private institutions (Cohen, 1998). In the twenty-first century, higher education has been described as a mature industry. In most regions and states, the institutional structures that will serve the nation for the foreseeable future are established and standing. This is not only true for institutions of higher education. Quite possibly, the basic institutional infrastructure of the healthcare, library systems, public transportation, performing arts facilities, and museums is largely established.

If the motivation of donors is to achieve some sort of lasting legacy through their giving, this impetus will need to find its expression in some other form than institution building (Strout, 2007b). We have run through a generation or more of creating campus buildings as "naming opportunities" for donors, but even this approach has limits. We have moved to naming "chairs" (figuratively for now), laboratories, schools, plazas, and libraries.

Satisfying the motivation to make a transforming difference through a transactional process is likely to tax our creative energies for some time to come (Worth, 2002). It is possible that the next expression of this arrangement is already manifested in the ways in which "new philanthropy" is being practiced inside and outside of higher education. Donors increasingly want to associate their giving with the elimination or amelioration of some major human dilemma. Hence we see major gifts associated with the founding of cancer centers, research on depression, or programs for the elimination of malaria, hunger, or child poverty.

In many ways, this expression of giving bridges two powerful influences in the history of philanthropy: creating an institutional legacy and addressing human need. Its potential for redefining the role of higher education in society is inspiring. It behooves college leaders to be careful in what they offer for "sale" in a transactional sense. Like the sale of religious indulgences, the sale of solutions cannot be approached without consideration of the ultimate delivery costs.

There is a general misunderstanding and persistent misuse of the concepts of transformation and transaction within our profession, and this has significant ramifications for the giving relationship.

The crucial distinction between interactions that are "transforming" and those that are "transactional" is at the heart of the conceptual framework and the resulting scholarship reflected in this special issue of the International Journal of Educational Advancement. Therefore it warrants a brief discussion of how these terms came to enter usage within our field and what they mean when applied to development activity within higher education.

While the concepts of "transaction" and "transformation" each have long individual histories, they were paired as conceptual distinctions in the writings of James McGregor almost 30 years ago, in reference to differing forms of social and political leadership 
(Burns, 1978). As with many terms associated with specific meaning in the social sciences, some precision has been lost as these terms became frequently used in public discourse. While leadership scholars continue to discuss the nuances of McGregor's points, his ideas are now part of the lexicon of many different fields and specialties, including the emerging professional language of philanthropy.

In essence, Burns (1978) makes these distinctions between transactional and transformational leadership:

Transactional leadership occurs when one person takes the initiative in making contact with others for the purpose of an exchange of valued things. (p. 19)

Transformational leadership occurs when one or more persons engage with others in such a way that leaders and followers raise one another to higher levels of motivation and morality. (p. 20)

It would be impossible to give a fully suitable treatment of transactional and transformational relationships in the context of this essay, but one might begin by asserting that a transformational act is not a transactional act with six extra zeroes following it! Despite the number of times that a university president might make reference to the "transformational" nature of a major gift to a university (see any issue of the Chronicle of Higher Education), the concept clearly goes much deeper than that. It may be that the best way to explore the distinction that Burns has suggested is through a metaphor.

Having raised a child to adulthood, I can point to a long series of transactional exchanges that began even before his actual birth. In some cases these were minor, automatic, and possibly inconsequential. In other cases, the transactions were substantial and significant, such as money to go to college, buy a home, and support his eating habits through adolescence. We do have a transactional history.

But our more-important role in each other's life is transformational. His birth made me a father. I could not have done that on my own. I made him a son. Our presence in each other's lives permanently and fundamentally changed each of our identities.

Key to understanding this metaphor is the recognition that transactional and transformational events can coincide in the same relationship. Transactional exchanges can begin and end, and could be (theoretically at least) organized, accounted, and summed. Etiologically, the basic idea is one of an action that crosses between two parties. A transformational engagement between two parties changes them both. They are simultaneously "formed" by what passes between them. I believe this is why Burns argues for a moral basis to transformational interchanges, as there is an important consideration of fundamental purpose and place in the world.

A university president might reflect carefully on this distinction before announcing (or seeking) a "transformational gift" for a public university. For that matter, we might all ask ourselves who has the right to suggest that any given private transactional event portends a transformational change in an institution that has been created for a public purpose. 
With this distinction established, the previous articles in this issue becometo my way of thinking-even more interesting. The history of changes at Portland State University began with the leadership of a president and a senior executive team that did construct a vision rooted in transformational change. It was, as Langseth and McVeety suggest, an evolutionary commitment but it had a revolutionary spirit. For a period of several decades, a mutually influencing transforming relationship was built between the university and the community it served and this provided a foundation for the changes in the 1990s and those that followed.

When Bloomfield and Kuhl explore some of the implications of raising support for teaching and learning in the STEM disciplines at Minnesota, we are given another good context to look at the degree to which the activities they relate are inherently transactional or transformational in their impact. To my view they are both as they have the ultimate goal of transforming individuals, institutional structures, disciplines, and the communities served by the institution across the state and world. By necessity, the Bloomfield and Kuhl article traces the course of transactional events, the underlying impact is one of reshaping identities and possibilities at many levels.

Strickland reminded us that the motivations of donors to enter into a transformational giving relationship with a college or university actually does suggest that they come through a different door (motivationally, at least) than one whose intentions are more simply transactional. Her article helps us to understand how transactional and transformational intent can coincide and even obscure each other, and how this might be unraveled by the gift officer or senior executive. We are in an age when the annual giving effort at some of our major institutions has become automated to the point of being "virtual," with no meaningful engagement between the university and the donor, aside from the transfer of funds over a wire. How do we build a conversation with a potential donor who holds the potential for something more - something more than more digits?

Jay Blanton's piece brings us back to the importance of language in our discourse regarding the role of higher education in society and how we approach our relationships with donors, the government, and others who support our mission. His examination of the concepts of "branding" and "identity marketing" bring us to the central dilemma that plagues a field that is so heavily oriented to transactional logic. It should be clear from the distinctions we have made earlier between transactional and transforming interactions that no market exists for genuine transformational activity. It demonstrates our paucity of professional language and the absence of better theoretically driven research that we conflate these ideas so frequently. This much is clear: The language of transformation should not be casually given to a process that does not warrant its use.

This last observation constitutes one of the most important summary conclusions that can be drawn from a close consideration of the several articles that comprise this special issue of the IJEA: we need more serious thought given to the implications of giving to higher educations that are 
themselves in such an obvious state of reinvention. The departure point for this special issue is unique-but it was meant only as a point from which to start a conversation within the profession. While the articles rendered here offer a good beginning, the underlying theoretical and empirical work that could support better research and ultimately contribute to better professional practice is scant, at best. There are at least three lines of inquiry that would be especially fruitful for researchers, practitioners, and external partners as they work together to make systemic changes in their communities, regions, and society at large.

While the concepts associated with engagement are not new, the formal adoption of this as an aspect of institutional mission (outside of Land Grant institutions in particular) is still emergent. As described in this issue, some theoretical frameworks are emerging to chart a course for this work on both practical and conceptual levels, but it is still incomplete. Specifically, the applied pieces in this special issue suggest that we may be able to sort out a few putative models that could be tested in a broader context. As these models find their way into use on other campuses, scholars could contribute by systematically evaluating their effectiveness weighing the effect of unique institutional missions, contexts, and other important factors. In so doing, researchers could provide a more robust set of explanations that might help institutional leaders map directions for their institutions in this emerging field of work.

Further, this special issue suggests important implications for the future of the advancement profession.
Specifically, how does adopting a transformational view of advancement align with our present values and current practices of fund raising? How might the emerging model of advancement and engagement inform the selection, recruitment, and training of advancement officers? Overall, what are the implications of a transformational model for professional development in the field? In short, we need more thoughtful reflection regarding ways to prepare, socialize, and nurture future generations of development officers informed by these values.

Finally, I suggest that we must take a reading of our external partners to consider their capacities and their inclinations to become more engaged in the work of the academy. Can we assume that this more-engaged approach to advancement will be readily accepted in a world of busy professionals, politicians, and potential donors? Does enough trust exist between our campuses and external partners to begin developing shared visions and shared cultures around transformational ideas? Particularly in light of the distinction made between transactional and transformational practices, what kinds of measurements are needed to help us track progress and evaluate long-term outcomes? These external considerations are critical to gauge as we seek to build more meaningful relationships with partners outside the immediate walls of our own professional practice.

In turn, we find ourselves faced with David Weerts' observations about the challenges we will face in organizing advancement and development functions in support of the engaged university. As his article points out, 
once transformation begins to take root within a system of relationships, every relationship that defines the system is subject to change. If we are to engage donors, community, or society in the transforming work we describe and seem to seek, it would be naive to suggest that we would not be changed ourselves.

\section{References}

American Association of State Colleges and Universities (2002), Greater Expectations: A New Vision for Learning as a Nation Goes to College, AASCU, Washington, DC.

Baldwin, R.G. and Krosteng, M.V. (1995), "Incentives in the academy: Issues and options," New Directions for Higher Education, 51, pp. 51-62.

Becker, W.E. and Lewis, D.R. (1992), The Economics of American Higher Education, Kluwer Academic Publishers, Boston.

Boyer, E.L. (1990), Scholarship Reconsidered: Priorities of the Professoriate, Princeton University Press, Lawrenceville, NJ.

Burns, J. (1978), Leadership, Harper Collins, New York.

Bush, V. (1945), Science: The Endless Frontier, Office of Scientific Research and Development, Washington, DC.

Chambers, T.C. (2005), “The special role of higher education in society: As a public good for the public good", in A.J. Kezar, T.C. Chambers and J.C. Burkhardt (eds.), Higher Education for the Public Good: Emerging Voices From a National Movement, Jossey-Bass, San Francisco.

Cohen, A.M. (1998), The Shaping of American Higher Education: Emergence and Growth of the Contemporary System, Jossey-Bass, San Francisco.

Duderstadt, J.J. and Womack, F.W. (2003), Beyond the Crossroads: The Future of the Public University in America, Johns Hopkins University Press, Baltimore, MD.

Ehrenberg, R.G. (2006), What's Happening to Public Higher Education?, Greenwood press, Portsmouth, NH.

Gardner, H. and Laskin, E. (1995), Leading Minds: An Anatomy of Leadership, Basic Books, New York.

Geiger, R.L. (1993), Research and Relevant Knowledge: American Research Universities Since World War II, Oxford University Press, New York.

Gumport, P. (2000), “Academic restructuring: Organizational change and institutional imperatives," Journal of Higher Education, 39, 1, pp. 67-91.

Immerwahr, J. (2004), Public Attitudes on Higher Education: A Trend Analysis, 1993-2003, The National Center for Public Policy and Higher Education, San Jose, CA.

Institute for Higher Education Policy (1998), Reaping the Benefits: Defining the Public and Private Value of Going to College, IHEP, Washington, DC.

Kerr, C. (2001), The Uses of the University, 5th edn., Harvard University Press, Cambridge, MA.

Lyall, K.C. and Sell, K.R. (2006), "The de facto privatization of American public higher education," Change, 38, 1, pp. 6-13.

National Forum on Higher Education for the Public Good (2002), The Role of Higher Education in Promoting Civic Engagement and Public Discourse: A Presentation of Findings from Four Focus Groups and a National Survey, National Forum on Higher Education for the Public Good, Ann Arbor, MI.

Nemec, M.R. (2006), Ivory Towers and Nationalist minds: Universities, Leadership and the Development of the American State, University of Michigan Press, Ann Arbor, MI.

Payton, R. (1988), Philanthropy: Voluntary Action for the Public Good, Oryx Press, New York.

Serlingo, J. (2003), "What Americans think about higher education," Chronicle of Higher Education, 99, 34, p. A10.

Strauss, W. and Howe, N. (1997), The Fourth Turning: An American Prophesy, Broadway Books, New York.

Strout, E. (2007a), "Looking for dollars in unusual places: Governor seeks unorthodox sources to pay for higher education," Chronicle of Higher Education, March 2, 2007. Retrieved June 10,2007 at http://chronicle.com/cgi2-bin/texis/ chronicle/search.

Strout, E. (2007b), “What's the big idea? As campaigns grow in size, fund raisers rack their brains for projects that will attract major donors," Chronicle of Higher Education, February 2, 2007, Retrieved June 10, 2007 at http://chronicle.com/cgi2-bin/texis/chronicle/ search.

Thelin, J. (2004), A History of American Higher Education, Johns Hopkins Press, Baltimore, MD.

Veysey, L.R. (1965), The Emergence of the American University, University of Chicago Press, Chicago.

Walshok, M.L. (1995), Knowledge without Boundaries: What America's Research Universities can do for the Economy, the Workplace and the Community, Jossey-Bass, San Francisco.

Worth, M.E. (2002), New Strategies for Educational Fund Raising, Praeger, Portsmouth, NH. 